\title{
Implementasi Layanan Kesehatan, Gizi, dan Perawatan dalam Menanamkan Disiplin Hidup Sehat
}

\section{Khairunnisa Ulfadhilah}

Institut Agama Islam Negeri Syekh Nurjati Cirebon, Indonesia khairunnisaulfadhilah51045@gmail.com

\section{Eti Nurhayati}

Institut Agama Islam Negeri Syekh Nurjati Cirebon, Indonesia etinurhayati@syekhnurjati.ac.id

\section{Maulidya Ulfah}

Institut Agama Islam Negeri Syekh Nurjati Cirebon, Indonesia ulfah@syekhnurjati.ac.id

Abstract: Implementation of Health, Nutrition, and care Services for Early Age Children. Early childhood health services, have routine activities of washing hands, maintaining personal health, and protecting the environment. Nutritional services have routine activities, namely the provision of balanced nutritional meals in schools. Care services have first aid management and control the child's physical condition (body temperature and injuries). However, there is no balance between school and home, while schools implement health, nutrition, and care services. This research was conducted to familiarize yourself with health, nutrition, and care services at An-Nur Cirebon PAUD; early childhood healthy life discipline; and the results of instilling the discipline of healthy life in early childhood. This research uses qualitative descriptive research, this research was chosen because it wanted to reveal more detail and clearly about health services, nutrition, care in instilling the discipline of a healthy life at PAUD An-Nur Cirebon. This research data collection technique is divided into 3 parts, namely observation, interviews, and documentation. The data analysis technique of this research is divided into 2, namely data reduction and triangulation. 
Keywords: Health services, nutrition, nursing, and healthy living disciplines.

Abstrak: Layanan kesehatan anak usia dini sangatlah berguna dan bermanfaaat guna memberikan pembiasaan baik pada anak, menjaga kesehatan agar anak terawat. Penelitian ini dilakukan di PAUD An-Nur Cirebon. Metode penelitian ini memakai deskriktip kualitatif, guna menjabarkan mengenai kesehatan, gizi, dan perawatan anak usia dini di PAUD An-Nur Cirebon. Sumber data yakni kepala sekolah, dan guru di PAUD An-Nur serta bidan yang bertugas mengecek kesehatan anak di lembaga PAUD An-Nur Cirebon. Teknik pengumpulan data penelitian ini terbagi menjadi 3 bagian yaitu observasi, wawancara, dan dokumentasi. Teknik analisis data penelitian ini terbagi menjadi 2 yaitu reduksi data dan triangulasi. Hasil penelitian yang telah dilakukan yakni guru maupun orang tua dapat bekerja sama dalam memberikan pelayanan kesehatan, gizi, dan perawatan dengan baik, dan sesuai arahan dari bidan yang bertugas mengecek kesehatan anak di PAUD An-Nur Cirebon. Selain itu, kesehatan, gizi maupun perawatan anak usia dini dapat dikontrol dengan baik serta dapat menerapkan pada anak.

Kata kunci: Layanan kesehatan, gizi, perawatan, dan disiplin hidup sehat.

\section{A. Pendahuluan}

Kesehatan, gizi dan perawatan untuk anak usia dini sangat penting diterapkan oleh orang tua maupun pihak sekolah serta mendisiplinkan anak dalam penerapan kesehatan, gizi maupun perawatan. Penelitian dilakukan mengenai layanan kesehatan, gizi, dan perawatan agar para guru-guru, lembaga sekolah maupun orang tua dapat menerapkan layanan kesehatan, gizi, da perawatan yang tepat, baik untuk anak sedari dini. Selain itu, dapat mengetahui ciri-ciri kesehatan anak, memperhatikan asupan nutrisi gizi anak, dan perawatan yang tepat serta orang tua maupun guru-guru didampingi penuh oleh bidan untuk mengecek kesehatan, gizi maupun perawatan anak. Kunjungan bidan ke PAUD An-Nur Cirebon memberikan pengutan untuk orang tua dengan guru, dan dapat berkonsultasi mengenai 
kesehatan, gizi, dan perawatan anak. Layanan kesehatan, gizi, dan perawatan mempunyai ciri khas berbeda dalam menerapkan pada anak yakni terletak pada konsultasikan dengan bidan yang bertugas untuk mengecek kesehatan, gizi, dan perawatan anak di PAUD An-Nur Cirebon. Layanan kesehatan, gizi maupun perawatan sangat berkaitan dengan dunia PAUD sebab anak usia dini sedang dalam masa golden age dimana waktu yang tepat untuk diberikan stimulasi, pembiasaan yang baik untuk menjaga kesehatan anak, diberikan asupan nutrisi yang bergizi, dan dapat melakukan perawatan pada anak serta dapat pertolongan pertama pada anak saat mengalami luka.

Layanan kesehatan anak usia dini, memiliki kegiatan rutin mencuci tangan, menjaga kesehatan diri dan menjaga lingkungan. Layanan gizi memiliki kegaiatan rutin yaitu pemberian makanan gizi seimbang disekolah. Layanan perawatan memiliki penanganan dengan P3K dan mengontrol kondisi fisik anak seperti suhu tubuh ataupun luka (Penyelenggaraan, 2015). Namun realita tidak ada keseimbangan antara disekolah, dan dirumah, disekolah menerapkan cara pengenalan lingkungan hidup 10 menit membersihkan lingkungan, pembiasaan menjaga kesehatan seperti mencuci tangan, menggosok gigi ketika dirumah tidak diajarkan, dan tidak ada penerapan (Wulandari \& Asmawi, 2021.).enerapkan pemberian makanan gizi seimbang namun ketika dirumah orang tua tidak menerapkan untuk anaknya (Anhusadar, 2021). Namun realita di PAUD An-Nur Cirebon tidak ada keseimbangan antara disekolah dan dirumah, disekolah menyediakan P3K namun dirumah tidak menyediakan. Tumbuh kembang anak memanglah sangat penting distimulasi maupun diterapkan, namun terdapat layanan yang perlu ditanamkan, dicontohkan, diterapkan, dilakukan pemeriksaan, diberi asupan nutrisi 4 sehat 5 sempurna yaitu kesehatan, gizi, dan perawatan sebab akan menunjang tumbuh kembang anak (Kesehatan \& Usia, 2018).

PAUD An-Nur Cirebon merapkan 3 layanan tersebut agar menerapkan kesehatan, gizi, perawatan anak dalam lingkungan sekolah, menanamkan rasa disiplin hidup sehat pada anak, dan menanamkan disiplin hidup sehat dilingkungan sekolah maupun pembiasaan anak ketika berada dirumah ataupun dimana saja. Penelitian ini bertujuan untuk mengetahui layanan 
kesehatan, gizi, dan perawatan di PAUD An-Nur Cirebon; disiplin hidup sehat anak usia dini; hasil menanamkan disiplin hidup sehat anak usia dini. Penelitian ini dilatar belakangi Peraturan Presiden Nomor 60 Tahun 2013 mengenai PAUD Holistik Integratif, sebagai bentuk komitmen pemerintah dalam menjamin terpenuhinya hak tumbuh kembang anak usia dini dalam hal pendidikan, kesehatan, gizi, perawatan, pengasuhan, serta perlindungan, dan kesajahteraan anak. Pelaksanaan PAUD Holistik Integratif dengan cara stimulan, berkesinambungan dan kompetetitif. Perencanaan layanan kesehatan mempunyai jadwal pemeriksaan anak oleh bidan, jadwal pemeriksaan anak oleh pendidik. Perencanaan layanan gizi mempunyai jadwal pemberian makanan gizi seimbang, dan perencanaan layanan perawatan menyediakan obat-obat dikotak P3K. Pelaksanaan layanan kesehatan mempunyai pemeriksaan anak oleh bidan, pemeriksaan anak oleh guru, dan pelaksaan layanan perawatan mengobati luka anak dengan obat-obatan dikotak P3K. Hasil layanan kesehatan orang tua akan terbantu oleh pemeriksaan bidan, dan guru. Hasil layanan gizi akan mempengaruhi gizi pada anak ketika disekolah maupun dirumah, orang tua bekerja sama dengan guru untuk membawakal bekal untuk anak disekolah, dan hasil layanan perawatan luka anak segera ditangani oleh guru.

Pembelajaran sangat dibutuhkan oleh anak, dan paling utama untuk mempersiapkan untuk jenjang selanjutnya (Ra \& Bima, 2021). Dalam kehidupan anak sebab anak perlu dibekali ilmu serta orang tua ataupun pendidik perlu menyiapkan sedari awal (Inten et al., 2019). Anak dalam keluarga, dan didikan seorang ibu kepada anak-anaknya (Islam et al., 2021). Terlebih jika anak berusia dini dalam masa golden age (masa keemasan) hanya datang sekali seumur hidup maka tidak boleh disiasiakan pada masa tersebut (Yaswinda et al., 2020). Pembelajaran di sekolah yang bisa dikontrol oleh guru disekolah (Wulandari \& Asmawi, 2021). Enam aspek yang perlu dikembangkan di pendidikan anak usia dini mengacu pada peraturan yang sudah ditetapkan (Penyelenggaraan, 2015). Orang tua bisa memberikan anaknya fasiltas di lembaga formal sebagai pijakan awal bagi anak agar berkembang secara optimal (Warmansyah, 2020). Layanan kesehatan, gizi, dan perawatan agar tujuan layanan kesehatan dan gizi berdampak baik dengan aspek anak dalam usia dini yang sudah dipaparkan oleh 
Petunjuk Teknis Penyelenggaraan PAUD Holistik Integratif (Kemdikbud, 2015). Layanan kesehatan sangat penting diberikan pada anak sebab dapat menjadi sarana pendukung guna mencegah permasalah yang dapat terjadi pada anak. Untuk mencegah permasalah dibutuhkan layanan dikhususkan anak usia dini untuk mencapai kesehatan secara optimal. Layanan kesehatan dapat menunjang tumbuh kembang anak secara optimal dengan adanya menjaga kesehatan anak, dan kebersihan anak serta lingkungan bersih di sekolah maupun di rumah. Perilaku kesehatan anak dapat distimulasi sedari dini guna mencegah dari penyait, apabila layanan kesehatan tidak ditanamkan sedari dini dapat berefek pada permasalahan kesehatan anak yang sering muncul terjadi.

\section{B. Pembahasan}

\section{Layanan Kesehatan}

Layanan kesehatan, gizi, dan perawatan diambil dari PAUD Holistik Integratif merupakan pelayanan diperuntukan anak usia dini disebuah lembaga PAUD. Manfaat adanya layanan kesehatan, gizi, dan perawatan yakni timbulnya rasa peduli akan tumbuh kembang anak oleh pihak lembaga serta bekerja sama dengan bidan setempat guna terpenuhinya tumbuh kembang anak dalam hal pendidikan, kesehatan, gizi, perawatan, pengasuhan, perlindungan, dan kesejahteraan pada anak (Warmansyah, 2020). Lembaga formal mulai jenjang RA perlu menerapkan PAUD Holistik Integratif sebab komitmen Pemerintah maupun Kementerian Pendidikan dalam membangun, dan menciptakan penerus bangsa yang lebih baik (Anhusadar, 2021). Program PAUD Holistik Integratif adalah tanggung jawab semua pihak, dan mempunyai peran nya masing-masing. Layanan kesehatan yang sudah diterapkan oleh PAUD An-Nur Cirebon berdampak pada kualitas kesehatan anak, dan jika anak terindikasi sakit akan segera ditangani oleh pihak guru untuk diberikan obat, dan memberitahukan orang tua. Selain itu, aspek perkembangan anak akan berdampak pada kesehatan anak (Inten et al., 2019). Selaras dengan paparan Inten, dalam siklus anak yang disekolah mempunyai peran penting dan berkaitan erat satu sama lain mak dariitu, pendidik dan lembaga sekolah perlu mengutamakan hal tersebut pada anak. Upaya melakukan layanan kesehatan bagi anak, 
sasarannya yaitu anak pra sekolah maupun sekolah dini, bertujuan menyelenggarakan usaha kesehatan (Warmansyah, 2020). Pertumbuhan dan perkembangan anak usia dini seoptimal mungkin sesuai fase tahapannya, menanamkan disiplin hidup sehat (Kesehatan \& Usia, 2018).

Pendidik mempunyai peran penting dalam membentuk, menumbuhkan kesadaran anak-anak untuk mencuci tangan, menggosok gigi, mengunting kuku yang kotor, dan panjang. Kesehatan bagi anak di PAUD An-Nur Cirebon sangat utama diterapkan, pendidik serta yayasan sekolah perlu kerja sama untuk menciptakan lingkungan sekolah yang sehat agar anak tidak terkena penyakit. Selain itu, terdapat pemeriksaan oleh bidan agar kesehatan anak terkontrol, dan dicatat hasil pemeriksaan anak oleh bidan lalu disetorkan kepada pendidik kemudian berkomunikasi dengan orang tua mengenai hasil kesehatan anak dalam kerja sama orang tua dengan pendidik sangat penting untuk tumbuh kembang anak agar seimbang. Menurut Maulidya Ulfah, bahwasanya keluarga mempunyai andil besar dalam wujudkan pendidikan berbasis holistik, dan integratif. Selaras dengan pemaparan di atas, keluarga perlu menerapkan holistik integratif pada anak ketika dirumah, dan membiasakan anak dikehidupan sehari-hari sebab penting sekali menerapkan sedari dini. Sebab jenjang PAUD perlu komprehensif dan terintegrasi dari pihak bersangkutan (Ulfah, 2019). Holistik integratif adalah program dari pemerintah untuk melakukan perubahan dalam pendidikan yang tepat untuk anak usia dini terdapat 5 layanan. Jika yang tidak diperiksa kesehatannya melalui program pemerintah kemudian sekolah menerapkan program tersebut, dan diaplikasikan pada anak-anak disekolah. Manfaat dari penerapan program tersebut anak-anak bangsa akan menjadi generasi yang sehat, cerdas, tangguh berkarakter bekerja sama dengan pihak kesehatan setempat, orang tua.

Layanan kesehatan bagi anak usia dini sangat penting diterapkan sedari dini ketika di rumah maupun disekolah (Pagarwati \& Rohman, 2020). Peran pendidik sangat dibutuhkan dalam memberikan pelayanan kesehatan pada anak selama berada di lingkungan sekolah, memberikan fasilitas untuk mengecek kesehatan anak, dan memberikan stimulasi menjaga kesehatan pada anak. Selain dapat memberikan contoh yang baik, pendidik, dan menjaga kebersihan diri sebagian dari 
iman. Lingkungan sekolah perlu diperhatikan dalam segi kebersihan agar kesehatan anak tidak terganggu sebab lingkungan yang kotor akan mengakibatkan kesehatan anak terganggu. Layanan kesehatan yang diterapkan PAUD An-Nur Cirebon seperti mengecek tinggi badan, berat badan anak, mengecek gusi anak oleh pendidik beserta bidan.

\section{Layanan Gizi}

Gizi merupakan asupan nutrisi yang mempunyai kadar gizi yang baik bagi tubuh manusia (Rusilanti, 2015). Manfaat asupan gizi terbaik untuk anak usia dapat menjaga maupun memelihara kesehatan sebab gizi sangat berkaitan erat dengan kesehatan dan peningkatan kualitas hidup. Gizi yang baik bisa membantu mengoptimalkan fungsi tubuh, mencegah serta membantu penanganan penyakit. Gizi merupakan sumber energi untuk beraktivitas, bergerak, berpikir, dan tubuh membutuhkan energi yang mencukupi. Energi tersebut didapatkan dari gizi yang dikonsumsi sehari-hari. Gizi tepat untuk anak usia dini guna pemberian gizi sehat disarankan dimulai sejak anak dalam usia kandungan hingga usia 3 tahun untuk membantu mengembangkan pertumbuhan sel-sel otak pada anak sejak bayi. Dari usia kehamilan 6 bulan hingga anak berusia 2 tahun yakni pertumbuhan anak akan sangat cepat karena diperlukan banyak gizi untuk menyeimbangkan. Gizi penting yang dibutuhkan anak usia dini yakni protein, karbohidrat, Vitamin B1, B6, asam folat, yadium, zat besi, seng, AA, DHA, sphingomyelin, sialic acid, dan asam-asam amino seperti tyrosine maupun tryptophan. Selain itu, anak usia dini perlu dibiasakan pola makanan sehat sehingga masa pertumbuhan anak, zat gizi yang mengandung energi, protein, vitamin, kalsium, dan zat besi wajib dikonsumsi anak. Orang tua sebaiknya perhatikan hal ini agar anak terbiasa dengan pola makan sehat sejak dini yakni hindari makanan jajanan dari luar rumah, kenalkan dengan berbagai macam makanan sehat, biasakan sarapan pagi, dan beri makanan bekal saat ke sekolah, hindari kegemaran terhadap satu jenis makanan. Makanan merupakan kebutuhan pokok yang sangat wajib dikonsumsi oleh manusia. Makanan bagi anak dapat memberikan nutrisi yang baik ketika makanan 4 sehat 5 sempurna terpenuhi dengan baik yang dikonsumsi oleh anak (Putri Abadi \& Suparno, 2019). Gizi anak akan berpengaruh besar bagi kesehatan anak, dan 
dapat menunjang keaktifan anak (Irma et al., 2019). Gizi baik dapat menunjang dari segi faktor sel-sel syaraf anak terlebih jika anak usia dini diberikan protein akan sangat baik pada otak, dan makanan bergizi lainnya (Suryaningsih et al., 2019).

Orang tua perlu memperhatikan asupan makanan anak sebab berdampak pada tumbuh kembang anak, begitupun pendidik perlu memperhatikan asupan makanan anak ketika disekolah, meperhatikan orang yang berjualan setidaknya harus menyediakan jajanan yang sehat dan tidak mengandung yang akan membahayakan kesehatan anak (Huliatunisa et al., 2020). Selaras dengan pemaparan di atas, peran sangat besar dipegang oleh orang tua ketika dirumah dan pendidik ketika disekolah keduanya perlu komunikasi dengan baik mengenai makanan anak sebab akan berpengaruh pada kesehatan anak jika anak mengalami sakit maka anak tidak akan berangkat sekolah dan akan tertinggal pelajaran disekolah. Gizi dapat membantu tumbuh kembang anak, memiliki manfaat yang optimal pada tubuh anak dapat membantu mengoptimalkan 6 aspek perkembangan anak (Wulandari \& Asmawi, 2021). Asupan gizi akan berkontribusi pada masa depan anak (Ulfah, 2019).

Penyebab akan kekurangan gizi pada anak dapat disebabkan seperti pendapatan orang tua yang minim akan berpengaruh pada asupan gizi anak, sanistasi dan lingkungan social sehingga anak tidak selayaknya mendapatkan asupan nutrisi dengan baik. Pemberian makanan sehat dapat menunjang tumbuh kembang anak, orang tua dapat memberikan stimulasi melalui asupan nutrisi yang bergizi pada anak. Orang tua dapat mengawasi asupan nutrisi anak pada saat di rumah maupun ketika anak sekolah, dan memberikan bekal makanan sehat pada anak. Anak usia dini mempunyai rasa ketertarikan membeli makanan karena warna yang mencolok, dan unik maka dari itu orang tua perlu membuat bekal makanan yang dapat menarik perhatian anak namun makanan yang bernutrisi guna merangsang melalui makanan yang bergizi. Selain makanan yang mengadung gizi tinggi, orang tua dapat memperhatikan dari segi kebersihan penyajian maupun pembuatan makanan jika membeli diluar.

\section{Layanan Perawatan}

Perawatan yang dianjurkan oleh pemerintah dalam cangkupan holistik integratif (Kemdikbud, 2015). Penyediaan 
obat-obat di P3K secara lengkap agar pertolongan pertama sederhana yang dapat dilakukan orang awam (Lestari, 2017). Sekolah menimalisir untuk anak tidak mengalami kecelakaan disekolah pada anak ketika disekolah yaitu menyiapkan lingkungan sekolah yang aman, menyediakan alat permainan ataupun mainan dilingkungan sekolah seperti ayunan dengan memasang alat yang aman agar meminimalisir terjadinya kecelakaan, menyediakan kamar mandi yang bersih, tidak licin bagi anak, dan halaman sekolah yang aman memakai pagar agar terhindar anak keluar dari lingkungan sekolah. Perawatan anak disekolah maupun dirumah perlu diperhatikan secara benar, dan tepat (Lina et al., 2019). Selain itu, peran pendidik ataupun kepala sekolah bekerja sama dan berkoordinasi penuh jika kekurangan akan hal menunjang perawatan anak disekolah dapat meminta bantuan kepada yayasan lembaga sekolah, penilik, Himpaudi setempat, dan orang tua (Oktaviani, 2021).

Peran pendidik dalam menanamkan perawatan pada anak terletak pada pemeriksaan kuku pada anak, memberikan contoh ketika memakai pakaian perlu diganti jika sudah kotor, bau dan perawatan tubuh pada anak. Disisi lain, pendidik selain memberikan contoh, penanaman mengajarkan pula pada anak mengenai perawatan tubuh perlu bersih sebab bersih adalah sebagian dari iman. Perawatan yang baik pada tubuh akan menangkal penyakit, virus dan badan anak pun akan terlihat bersih, wangi, segar (Putri Abadi \& Suparno, 2019). Pembiasaan sedari dini sudah diterapkan dan diaplikasin secara tepat maka akan berpengaruh besar ketika anak sudah beranjak dewasa. Anak selalu mengingat dan menerapkan ketika anak sudah tumbuh dewasa di masa yang akan datang. Maka itu pendidik, ayah ibu perlu menerapkan serta melakukan pembiasaan sedari dini anak akan dapat merekam dengan baik kemudian akan mencontohkan walaupun secara bertahap.

\section{Penanaman Disiplin Hidup Sehat}

Menurut Charles Schaefer disiplin yaitu pembelajaran dari orang tua ataupun pendidik agar dapat membiasakan sedari dini mungkin (Anhusadar, 2021). Disiplin dapat dikatakan sebagai mengajarkan anak dalam perilaku moral, dan tidak dianjurkan orang tua melakukan paksaan terhadap anak untuk menerapan disiplin pada ank namun hendaknya dilakukan secara bertahap makanak akan mencontohkan (Pagarwati \& 
Rohman, 2020). Tujuan dari disiplin yaitu agar membentuk perilaku anak sedari dini, selain itu menanamkan disiplin dalam hidup bersih atau dapat dikatakan dengan PHBS (Perilaku Hidup Bersih Sehat) (Moerad et al., 2019). Penting sekali ketika anak usia dini ditanamkan displin hidup sehat agar disekeliling memiliki jiwa sehat sehingga memiliih peran penting dalam ineraksi dengan masyarakat luas (Dian Wuri Astuti et al., 2020). Membentuk perilaku sehat pada anak usia dini sebab usia dini adalah fase golden age (masa keemasan) fase ini sel syaraf otak anak menduduki angka tertinggi yaitu $80 \%$ perkembangan otak anak dalam sel-sel syaraf (Maulidia \& Hanifah, 2020). Dalam fase anak pra sekolah kemampuan mengingat anak tinggi sehingga perlu memaksimalkan stimulasi pada anak saat fase ini oleh orang tua maupun pendidik (Tabi'in, 2020). Rangsangan tumbuh kembang anak oleh keluarga setiap saat dengan metode menyenangkan, pemantuan perkembangan dilakukan setiap hari secara bertahap (Purba \& Gusar, 2020).

Orang tua dapat memberikan penanaman dengan cara mencontohkan pada anak mengenai kebersihan diri maupun lingkungan sekitar. Mengajarkan dengan cara paling mudah melakukan secara bertahap sesuai usianya yakni, membuang sampah pada tempatnya, menyimpan sepatu ke rak sepatu, menyimpan pakaian kotor ke tempat mesin cuci, memakai sendal atau sepatu jika berpergian dari rumah, belajar menggosok gigi dengan benar 2 kali sehari setelah sarapan dan sebelumtidur, mandi sehari 2 kali, mencuci kaki, mengajarkan anak toilet training. Orang tua perlu mengajarkan cara menyapu dan membersihkan rumah dalamkehidupan sehari-hari anak. Orang tua dapat memberikan contoh pada anak dalam pembiasaan sehari-hari sebab anak usia dini dalam tahap peniru yang ulung, maka dari itu orang tua sebaiknya memberikan contoh dengan baik sehingga anak akan merekam kemudian menirukan dari orang tua (Angka, 2021). Orang tua adalah contoh untuk anak sehingga anak akan mencontohkan apa yang telah dilakukan oleh orang tua, dan dalam tahap golden age dilakukan stimulasi dan rangsangan yang optimal guna aspek perkembangan anak sesuai tahapan (Ra \& Bima, 2021). 


\section{Metode}

Penelitian ini menggunakan metode kualitatif untuk menjabarkan hasil penelitian (Sugiyono, 2015). Metode pengumpulan data dalam penelitian ini menggunakan wawancara, dokumentasi, dan observasi. Selain itu, sumber data terbagi menjadi dua yaitu primer dan sekunder. Sumber data primer diperoleh dari kepala sekolah, guru, bidan, dan orang tua. Sedangkan sumber data sekunder yakni penelitian yang diperoleh melalui media perantara berupa buku, catatan, dan arsip. Teknik pengumpulan data dilakukan dengan dokumentasi mengenai layanan kesehatan, gizi, perawatan dan disiplin hidup sehat anak berupa foto-foto maupun video. Riset ini memakai analisis data kualitatif agar dari hasil tersebut dideskripsikan, dan menjabarkan mengenai kata-kata tertulis ataupun melalaui perkataan.

\section{Hasil Penelitian}

Berdasarkan hasil penelitian yang bertempat PAUD An-Nur Cirebon dilakukan melalui tahapan perencanaan seperti kesehatan anak usia dini sesuai dengan usia pra sekolah. Layanan kesehatan, gizi, dan perawan mempunyai peran andil dalam hal ini untuk perencanaan layanan kesehatan, pihak sekolah bekerja sama dengan pihak bidan setempat. Mendatangkan bidan yang sudah bekerja sama dengan pihak pukesmas setempat dan kunjungan dokter 2 bulan sekali di PAUD An-Nur Cirebon, kemudian kunjungan bidan dan dokter diadakan 2 bulan sekali atau 6 bulan sekali, disesuaikan kebutuhan anak-anak ketika di sekolah dan menyesuaikan dengan waktu bidan dan kunjungan dokter. Jika anak sehat maka berpengaruh pada tumbuh kembang anak, akan melakukan kegiatan dan berekspolarasi kemampuanya. Selaras dengan (Kemdikbud, 2015) bahwa layanan kesehata, gizi, dan perawatan dalam pengawasan tenaga pendidik, kepala sekolah, bidan untuk memeriksa anak dalam lingkungan sekolah kemudian dapat didiskusikan dengan orang tua, dan orang tua akan menambah wawasan mengenai layanan kesehatan, gizi, perawatan bagi anak dengan tepat serta dapat berkonsultasi dengan bidan jika mengalami kendala dalam kesehatan anak, asupan nutrisi untuk anak, dan merawat tubuh anak usia dini. 
(Ulfah, 2019) berpendapat bahwa pendekatan yang memerlukan kesinambungan layanan bagi anak usia dini. Kerjasama antar berbagai pihak sangat diperlukan untuk keberhasilan dalam lembaga pendidikan anak usia dini. Selerasa dengan pendapat diatas bahwa pelaksanan seperti layanan kesehatan di PAUD An-Nur Cirebon sesuai yang dihadapkan oleh kepala sekolah, guru-guru dan bidan. Pelaksanaan layanan kesehatan, pemeriksaan kesehatan anak dari bidan meliputi gusi, gigi dan kesehatan anak lainnya di PAUD An-Nur Cirebon untuk pemeriksaan gusi, gigi dilakukan pemeriksaan satu anak terlebih dahulu agar memudahkan bidan memeriksa. Pemeriksaan oleh bidan diadakan 2 bulan sekali di PAUD AnNur Cirebon, bidan meminta bekerja sama dengan pendidik, dan orang tua agar membiasakan anak untuk menjaga kesehatan nya, memilah memilih asupan makanan anak, dan menggosok gigi. Pemeriksaan rutin dari pendidik untuk berat badan, tinggi badan, gigi, kebersihan rambut dan kuku jari, pengenalan lingkungan hidup (PLH) untuk membersihkan lingkungan contohnya membuang sampah pada tempatnya, pembiasaan menjaga kesehatan untuk membuang sampah pada tempatnya, mencuci tangan dan menggosok gigi. Hasil layanan kesehatan pemeriksaan rutin dari guru berat badan, tinggi badan, gigi, kebersihan rambut dan kuku jari terpantau dengan baik adanya pemeriksaan rutin oleh guru. Pembiasaan menjaga kesehatan anak-anak terbiasa membersihkan tangan menggunaka sabun, menggosok gigi dan membuang sampah pada tempatnya.

(Oktaviani, 2021) menjelaskan bahwa penerapan layanan kesehatan, gizi, dan perawatan perlu diterapkan di lembaga pendidikan anak usia dini agar dapat mengontrol dengan baik dilingkungan sekolah, dan ajang orang tua untuk dapat berkonsultasi dengan tenaga pendidik, dan bidan. Seleras dengan pemaparan diatas, bahwa perlu diterapkan layanan kesehatan, gizi, dan perawatan di lembaga pendidikan anak usia dini. Berdasarkan hasil observasi perencaan layanan gizi di PAUD An-Nur Cirebon pada anak usia dini sangat mempengaruhi akan perkembangan dan pertumbuhan anak. Pengaruh pangan berdampak pada organisme hidup, makanan yang dikonsumsi oleh manusia. Berdasarkan hasil wawancara dengan pendidik, jadwal pemberian makanana gizi seimbang disekolah diadakan 1 minggu sekali pada hari sabtu. PAUD AnNur Cirebon memiliki program pemberian makanan gizi 
seimbang di sekolah, kepada anak-anak didiknya disekolah. Gizi seimbang adalah susunan makanan sehari-hari yang mengandung zat-zat gizi dalam jenis dan jumlah yang sesuai dengan kebutuhan tubuh dengan memperhatikan prinsip keberagaman atau variasi makanan, aktivitas fisik, kebersihan dan berat badan ideal sekolah, pendidik dan orang tua dalam hal pemberian makanan tambahan sehat. Pemberian makanan gizi seimbang di PAUD An-Nur Cirebon, menu makanan yang bervarian setiap 1 minggu sekali. Agar anak tidak bosan jika menu makanan, menu makanan gizi seimbang berbeda-beda. Dalam pembuatan makanan gizi seimbang oleh kepala sekolah dan dibantu dengan wali murid. Asupan makanan dan minuman memenuhi gizi seimbang yang diperlukan untuk anak-anak ketika berada disekolah, akan lebih sehat jika anak megkonsumsi makanan dan minuman bergizi. Terdapat gerakan agar anak mengurangi snack MSG, sekolah pun menyediakan makanan gizi seimbang.

Pelaksanaan layanan gizi di PAUD An-Nur Cirebon sesuai dengan yang dianjurkan kepala sekolah, pendidik dan bidan terhadap anak dan orang tua nya, meliputi pemberian makanan gizi seimbang disekolah dengan cara memberikan makanan gizi seimbang yang diadakan 1 minggu sekali. Setiap minggunya mempunyai menu makanan gizi seimbang yang berbeda-beda, anak tidak bosan untuk makan. Pembuatan makanan gizi seimbang oleh ibu kepala sekolah dan dibantu beberapa wali murid, membutuhkan banyak orang untuk dibuatkan makanan gizi seimbang dan menyiapkan. Memperhatikan gizi seimbang bagi anak dapat berpengaruh pada fisik dan sehat mental pada anak. Salah satu menu makanan gizi seimbang di PAUD An-Nur Cirebon yaitu roti, susu, dan bubur kacang hijau. Mengurangi makanan snack MSG dan jajan sembarangan, pemberian makana sehat dari rumah yang merupakan orang tua menyediakan makanan bekal untuk anak disekolah, penimbangan berat badan dan pengukuran tinggi badan. Orang tua dianjurkan untuk pemberian makanan sehat di rumah, agar gizi anak diawasi ketika di rumah dan di sekolah. Makanan sehat yang dibuatkan oleh orang tua, bersih serta sehat. Menyediakan program PMT (Pemberian Makanan Tambahan) diadakan 1 minggu sekali oleh PAUD An-Nur Cirebon akan berdampak pada asupan, dan kebutuhan gizi pada anak menu yang bervarian pemberian makanan gizi seimbang seperti susu, roti, dan bubur 
kacang hijau. PAUD An-Nur Cirebon mempunyai kegiatan rutin layanan gizi seperti jadwal pemberian makanan gizi seimbang, arahan anak mengurangi snack MSG, pemberian makanan gizi seimbang yang diadakan 1 minggu sekali untuk menu yang bervarian agar anak tidak bosan. Mengurangi anak jajan sembarangan dengan menghimbau orang tua membawakan bekal untuk anak-anaknya berangkat ke sekolah, dan pemenuhan gizi seimbang ketika anak-anak dirumah. Guru menghimbau untuk orang tua anak-anak didik untuk memberikan makanan gizi seimbang kepada anak nya ketika dirumah, dan mengurangi makanan cepat saji tidak sehat untuk anak. Hasil layanan gizi di PAUD An-Nur Cirebon Pemberian makanan gizi seimbang di PAUD An-Nur Cirebon mengurangi anak makanan sncak MSG dan mengurangi anak jajan sembarangan dalam lingkungan sekolah. Keseimbangan pemberian makanan gizi seimbang disekolah dan dirumah, orang tua memberikan makanan gizi seimbang dirumah. Timbangan berat badan dan pengukuran tinggi badan anak selalu terkontrol oleh pendidik diadakan 1 bulan sekali. Pemaparan diatas sejalan dengan pendapat (Salehudin et al., 2020) bahwa layanan kesehata, gizi, dan perawatan perlu adanya pemberian makanan gizi minimal seminggu sekali di lembaga pendidikan anak usia dini, menu yang bervarian guna anak tidak cepat bosan, dan terpenuhi gizi dengan adanya pemberian makanan sehat untuk menunjung tumbuh kembang anak serta kegiatan anak selama dilingkungan sekolah. Selain itu, orang tua perlu dilibatkan dalam kegiatan ini agar dapat memberikan makanan sehat dan seimbang untuk anak selama dirumah serta mengawasi makanan anak saat diluar rumah.

Berdasarkan hasil riset pada perencanaan layanan perawatan di PAUD An-Nur Cirebon, bagian penting dalam mewujudkan program yang sudah terlaksana yakni P3K guna mengecek fisik anak. Jadwal P3K dilakukan ketika anak mengalami luka pada tubuhnya di lingkungan sekolah, guru mengobati luka pada tubuh anak. Jadwal setiap hari dilakukan oleh pendidik ketika di kelas untuk megecek fisik anak dilakukan setiap hari di kelas oleh pendidik masing-masing kelas. PAUD An-Nur Cirebon menyediakan alat P3K gunanya agar mengobati pertolongan pertama pada kecelakaan kecil ialah jatuh dan luka. Kondisi darurat dapat terjadi kapan dan dimana saja, ketika memberikan obat dan menolong anak ktika 
mengalami luka perlu menumbuhkan rasa tenang untuk menghindari rasa panik atau takut sebab dikhawatirkan memberika obat yang salah sehingga akan mengakibatkan luka korban semakin parah, dan cidera kemudian dilakukan pengobatan oleh pendidik ketika anak mengalami luka. Pertolongan pertama adalah pemberian pertolongan sederhana yang dapat meminimalisir luka anak semakin parah menggunakan seperti obat merah, hansaplas hal yang dapat dilakukan oleh siapa saja. Perencanaan layanan perawatan, kepala sekolah dan pendidik kelas maupun pendidik pedamping membuat peraturan kepada anak, untuk membersihkan kuku yang panjang dan kotor oleh orang tua, jika orang tua tidak meluangkan waktu untuk membersihkan kuku anak ketika dirumah maka guru lah yang membersihkan kuku sebelum masuk kelas. Tidak hanya perawatan kuku saja untuk anak-anak disekolah tetapi perawatan lainnya seperti merawat gigi agar bersih tidak bolong dan kebersihan lainnya.

Pelaksaan layanan perawatan di PAUD An-Nur Cirebon menyediakan obat-obat P3K yang lengkap dan sederhana untuk meminimalisir luka pada anak oleh pendidik ketika anak di dalam ruangan kelas. Penerapan perawatan di PAUD An-Nur Cirebon yakni melakukan pemeriksaan kuku anak-anak selain itu tak hanya pemeriksaan saja namun pendidik melakukan pemotongan kuku anak yang panjang, pendidik mengajarkan cara merawat badan seperti mandi sehari 2 kali, menganti pakaian jika sudah kotor, menggosok gigi sehari 2 atau 3 kali, mencuci tangan setelah melakukan kegiatan apapun, dan pendidik akan sigap memberikan perawatan pada anak ketika anak terluka, jatuh akan mengobati dengan alat P3K yang disediakan oleh sekolah seperti obat merah, antiseptik ataupun kayu putih. Sebab penting adanya P3K disekolah untuk sedia jika terdapat hal yang tidak diinginkan, selain itu P3K adalah pertolngan pertama sederhana untuk masyarakat.

Perawatan dapat diartikan juga sebagai pertolongan pertama adalah memberikan bantuan pada orang yan terluka seperti memberika obat merah, perban ataupun memberikan pereda nyeri hal tersebut mrupakan tindakan pertolongan yang semua orang bisa lakukan. Bahwa pertolongan pertama pada kecelakaan yang biasa kita kenal dengan istilah P3K (Usnawati et al., 2016). Dalam setiap instansi serta rumah harus ada penyediaan fasilitas P3K (Lina et al., 2019). Selaras dengan 
pendapat diatas, dengan adanya fasilitas yang tersedia maka seseorang diharapkan mampu menangani luka yang terjadi pada korban. Pihak pendidik perlu bekerja sama dengan orang untuk perencanaan layanan perawatan pada anak, perawatan pada anak sangatlah penting dilakukan dilingkungan sekolah maupun lingkungan rumah. Hasil layanan perawatan di PAUD An-Nur Cirebon mempunyai kotak P3K, anak mengalami luka terbantu dengan adanya kotak P3K mendapatkan pertolongan pertama oleh guru. Mengecek kondisi fisik anak ketika di kelas, akan terlihat suhu tubuh panas dan luka.

Penamaman disiplin hidup sehat yaitu mengajarkan mengenai hal disiplin hidup sehat pada anak sedari dini dapat dilakukan dengan bertahap namun secara signifikan dalam mengajarkan pada anak sebab anak tidak bisa sekaligus perlu waktu serta orang tua maupun pendidik (Aulina, 2013). Penjelasan diatas sesuai dengan hasil penelitian di PAUD AnNur Cirebon bahwa peran orang tua maupun pendidik diharapkan dapat saling membantu agar mengetahui keadaan penanaman displin hidup sehat bagi anak, ketika anak dirumah peran orang tualah yang sangat berdampak selain menstimulasi, orang tua perlu mencontohkan dalam kehidupan sehari-hari agar anak selalu mengingat sebab ingatan anak masih sangat kuat maka dari dari itu kesempatan bagi orang tua, dan membiasakan hidup sehat dan anak akan mencontohkan hal tersebut. Jika anak berada disekolah peran orang tua diganti sementar oleh pendidik, pendidik dan lembaga sekolah perlu mengutamakan disiplin dalam hidup sehat agr anak-anak terhidar dari penyakit.

Penanaman disiplin hidup sehat anak perlu ditanamkan oleh pendidik dengan cara mencontohkan terlebih dahulu, mempraktekan langsung mengenai disiplin hidup sehat maka anak akan merekam dan akan menirukan yang sudah dicontohkan oleh pendidik sebab ingatan anak masih kuat ketika usia dini mencapai $80 \%$. Orang tua mempunyai peran andil besar dalam hal ini selain orang tua perlu mencontohkan, perlu membiasakan ke dalam sehari-hari agar anak terus merekam kemudian mencontohkan akan terlihat perbedaan ketika orang tua yang stimulasi dengan bertahap, melakukan pembiasan secara rutin pada anak.

Layanan kesehatan, gizi, dan perawatan yang dilaksanakan oleh PAUD An-Nur Cirebon adalah menanamkan kesadaran 
terhadap pentingnya kesehatan anak dan dilakukan bersamasama. Dari hasil analisa penulis, ditemukan hubungan kemitraan antara PAUD An-Nur Cirebon dengan bidan, dan orang tua anak dalam memantau pertumbuhan dan perkembangan anak. Kemitraan tersebut dapat menjadi pondasi yang kuat bagi satuan PAUD untuk melaksanakan pelayanan dengan maksimal, mengacu pada tujuan layanan kesehatan, gizi, dan perawatan yaitu kesiapan anak usia dini baik kesiapan mental, spiritual, sosial serta intelektual dalam melaksanakan kegiatan pendidikan yang akan ditempuhnya kelak, serta dapat menjadi generasi penerus bangsa yang dapat bersaing di era global.

\section{E. Simpulan}

Layanan kesehatan, gizi, dan perawatan di PAUD An-Nur Cirebon sudah dapat menjalankan dengan baik pada anak didik sesuai dengan Petunjuk Teknis Penyelenggaran Holistik Integratif. PAUD An-Nur Cirebon bekerja sama dengan bidan untuk memeriksa kesehatan anak serta perawatan, dan berkonsultasi dengan bidan untuk varian menu bergizi sehingga pemberian makanan tambahan mempunyai nilai gizi yang baik untuk tumbuh kembang anak usia dini. Penyelenggaraan program PAUD Holistik Integratif memiliki landasan hukum Perpres No. 60 Tahun 2013 tentang Holistik Integratif. PAUD An-Nur Cirebon menyediakan makan siang 4 sehat 5 sempurna, mengecek kesehatan oleh bidan, dan dilakukan mengontrol perawatan anak.

\section{Referensi}

Angka, M. (2021). Penggunaan Media Box of Number and Alfabeth untuk Meningkatkan Kemampuan Kognitf, Bahasa dalam. 4(1), 67-77. https://doi.org/10.31004/aulad.v4i1.93

Anhusadar, L. O. (2021). Jurnal Obsesi : Jurnal Pendidikan Anak Usia Dini Penerapan Perilaku Hidup Bersih dan Sehat Anak Usia Dini di Tengah Pandemi Covid 19 Abstrak. 5(1), 463475. https://doi.org/10.31004/obsesi.v5i1.555 Aulina, C. N. (2013). Penanaman disiplin pada anak usia dini. 2(1), 36-49.

Dian Wuri Astuti, Fitri Nadifah, Yuliana Prasetyaningsih, Vixa Meindara, Anggraeni, Diah Irawati, \& May Tri Mulyani. 
(2020). Penyuluhan Perilaku Hidup Bersih Dan Sehat (PHBS) Di Dusun Berjo Wetan Godean Sleman Yogyakarta. J.Abdimas: Community Health, 1(1). https://doi.org/10.30590/jach.v1i1.232

Huliatunisa, Y., Alfath, M. D., \& Hendiati, D. (2020). CUCI TANGAN BERSIH MENGGUNAKAN SABUN. Jurnal Pasca Dharma Pengabdian Masyarakat, 1(2). https://doi.org/10.17509/jpdpm.v1i2.24027

Inten, D. N., Permatasari, A. N., Guru, P., Anak, P., Dini, U., Bandung, U. I., Komunikasi, I., \& Bandung, U. I. (2019). Jurnal Obsesi : Jurnal Pendidikan Anak Usia Dini Literasi Kesehatan pada Anak Usia Dini melalui Kegiatan Eating Clean. 3(2), 366-376.

https://doi.org/10.31004/obsesi.v3i2.188

Irma, C. N., Nisa, K., \& Sururiyah, S. K. (2019). Keterlibatan

Orang Tua dalam Pendidikan Anak Usia Dini di TK Masyithoh 1 Purworejo. Jurnal Obsesi : Jurnal Pendidikan Anak Usia Dini, 3(1), 214. https://doi.org/10.31004/obsesi.v3i1.152

Islam, P., Usia, A., \& Gresik, U. M. (2021). Jurnal Obsesi : Jurnal

Pendidikan Anak Usia Dini Peran Orang Tua dalam Mendukung Kegiatan Pembelajaran di Rumah pada Masa Pandemi Abstrak. 5(1), 549-558.

https://doi.org/10.31004/obsesi.v5i1.630

Kemdikbud. (2015). Petunjuk Teknis Penyelenggaraan PAUD Holistik Integratif di Satuan PAUD.

Kesehatan, P., \& Usia, A. (2018). Erida - Pengasuhan dan Pengembangan Kesehatan Anak Usia Dini.

Lestari, R. R. (2017). Pemberian Asi Eksklusif di Wilayah Kerja Puskesmas Tapung Perawatan Tahun 2015. Jurnal Obsesi : Jurnal Pendidikan Anak Usia Dini, 1(2), 97. https://doi.org/10.31004/obsesi.v1i2.20

Lina, L., Suryana, D., \& Nurhafizah, N. (2019). Penerapan Model Evaluasi CIPP dalam Mengevaluasi Program Layanan PAUD Holistik Integratif. Jurnal Obsesi : Jurnal Pendidikan Anak Usia Dini, 3(2), 346. https://doi.org/10.31004/obsesi.v3i2.200

Maulidia, A., \& Hanifah, U. (2020). Peran Edukasi Orang Tua terhadap PHBS AUD selama Masa Pandemi Covid-19. Musamus Journal of Primary Education, 3(1), 35-44. https://doi.org/10.35724/musjpe.v3i1.3078 
Moerad, S. K., Susilowati, E., Savitri, E. D., Rai, N. G. M., Windiani, W., Suarmini, N. W., Hermanto, H., Mahfud, C., \& Widyastuti, T. (2019). Pendampingan Pelaksanaan Program Perilaku Hidup Bersih dan Sehat (PHBS) Anak Usia Dini - Pos PAUD Terpadu Melati Kelurahan Medokan Ayu - Rungkut Surabaya. Sewagati, 3(3).

https://doi.org/10.12962/j26139960.v3i3.6016

Oktaviani, D. A. (2021). Penerapan PAUD Holistik Integratif pada Masa. 5(2), 1870-1882. https://doi.org/10.31004/obsesi.v5i2.995

Pagarwati, L. D. A., \& Rohman, A. (2020). Grandparenting Membentuk Karakter Anak Usia Dini di Masa Pandemi Covid-19. Jurnal Obsesi : Jurnal Pendidikan Anak Usia Dini, 5(2), 1229-1239.

https://doi.org/10.31004/obsesi.v5i2.831

Penyelenggaraan, P. T. (2015). Paud holistik integratif di satuan paud.

Purba, N., \& Gusar, M. R. S. (2020). Clean and Healthy Lifestyle Behavior (PHBS Program) for Children with Intellectual Disability. JPUD - Jurnal Pendidikan Usia Dini, 14(2), 275287. https://doi.org/10.21009/jpud.142.06

Putri Abadi, N. Y. W., \& Suparno, S. (2019). Perspektif Orang Tua pada Kesehatan Gigi Anak Usia Dini. Jurnal Obsesi : Jurnal Pendidikan Anak Usia Dini, 3(1), 161. https://doi.org/10.31004/obsesi.v3i1.161

Ra, D. I., \& Bima, B. (2021). Implementasi kurikulum 2013 (terpadu) di ra baiturrahman bima cirebon. 6(1), 47-58.

Rusilanti, M. D. (2015). Gizi dan Kesehatan Anak Prasekolah. PT Remaja Rosdakarya.

Salehudin, M., Yatun, S., Komariah, D. L., Eka, N., \& Aminda, R. (2020). Persepsi Guru Dalam Implementasi Holistik Integratif Pendidikan Anak Usia Dini Pada Kondisi New Normal. Jurnal Golden Age, 4(02), 394-406. https://doi.org/10.29408/jga.v4i02.2767

Sugiyono. (2015). Metode Penelitian Pendidikan. ALFABETA CV. Suryaningsih, A., Cahaya, I. M. E., \& Poerwati, C. E. (2019).

Implementasi Metode Experiential Learning dalam Menumbuhkan Perilaku Kesehatan dan Keselamatan Anak Usia Dini. Jurnal Obsesi : Jurnal Pendidikan Anak Usia Dini, 4(1), 187. https://doi.org/10.31004/obsesi.v4i1.317 Tabi'in, A. (2020). Perilaku Hidup Bersih Dan Sehat(Phbs) Pada 
Anak Usia Dini Sebagai Upaya Pencegahan Covid 19. JEA (Jurnal Edukasi AUD), 6(1), 58.

https://doi.org/10.18592/jea.v6i1.3620

Ulfah, M. (2019). Pendekatan Holistik Integratif Berbasis

Penguatan Keluarga pada Pendidikan Anak Usia Dini Full

Day. Jurnal Obsesi : Jurnal Pendidikan Anak Usia Dini, 4(1),

10. https://doi.org/10.31004/obsesi.v4i1.255

Usnawati, N., Setiyani, A., \& Subagyo. (2016). Pembinaan PAUD

holistik integratif dalam perspektif pencapaian target

SDIDTK. Jurnal Penelitian Kesehatan Suara Forikes, VII(3), 131-135.

Warmansyah, J. (2020). Program Intervensi Kembali

Bersekolah Anak Usia Dini Masa Pandemi Covid-19. Jurnal

Obsesi : Jurnal Pendidikan Anak Usia Dini, 5(1), 743.

https://doi.org/10.31004/obsesi.v5i1.573

Wulandari, M., \& Asmawi, M. (2021). Hubungan Status Gizi dan

Aktivitas Bermain melalui Keterampilan Gerak Dasar Anak

Taman Kanak-Kanak. 5(2), 1706-1717.

https://doi.org/10.31004/obsesi.v5i2.965

Yaswinda, Y., Yulsyofriend, Y., \& Sari, H. M. (2020). Analisis

Pengembangan Kognitif dan Emosional Anak Kelompok

Bermain Berbasis Kawasan Pesisir Pantai. Jurnal Obsesi :

Jurnal Pendidikan Anak Usia Dini, 5(2), 996-1008.

https://doi.org/10.31004/obsesi.v5i2.711 